\title{
Motivation, expectations and the gender pay gap for UK graduates
}

\author{
Arnaud Chevalier ${ }^{*}$ (UCD, LSE)
}

Draft 1.0. 10 October 2002

Preliminary and incomplete: Comments welcome

\begin{abstract}
:
The gender wage gap has long interested social scientists. Various theories have been put forward to explain the lower wages for women. Due to the richness of the data available, we can test whether employers discriminate against women or whether the gender gap stems from socialisation, differences in educational choice, occupational choice, or labour market attachment. Focussing on recent UK graduates, a wage gap of $12 \%$ is found as well as significant gender differences in the subject of graduation, sector of employment and feminisation of the job. Women also tend to be more altruistic and less career oriented than men, character traits that are less rewarded by employers.

The unexplained component of the gap is small and a large fraction of the gap can be explained by subject choice, job characteristics, motivation and expectation variables. Two third of women agree that they expect to take career breaks for family reasons and more than $1 / 3^{\text {rd }}$ of men expect their partner to sacrifice her career for childrearing responsibilities. These conservative attitudes affect women's wages even at an early stage of their career and are the single most important determinants of the gender wage gap.
\end{abstract}

Key words: gender wage gap, attitude

JEL codes: J16, J13, J29, J70

Acknowledgment: I am grateful to Augustin de-Coulon, Kevin Denny and Tarja Viitanen for comments that improved earlier versions of this paper. All remaining errors are solely mine.

\footnotetext{
${ }^{*}$ Corresponding author: Arnaud Chevalier, Institute for the Study of Social Change, University College Dublin, Dublin 4, Ireland. Tel: +353 (1) 716 4616, Fax: +353 (1) 716 1108, email: arnaud.chevalier@ucd.ie and Centre for the Economics of Education, London School of Economics, London WC2A 2AE, a.chevalier@lse.ac.uk.
} 


\section{Introduction}

A large literature on the gender wage gap exists (see Altonji and Blank, 1999 or Blau and Kahn, 2000, for recent surveys or Weichselbaumer and Winter-Ebmer, 2001, for a metaanalysis). Typically despite the introduction of equal opportunity legislations in the sixties and seventies, women are still paid between $20 \%$ and $40 \%$ less then men. Recent estimates for the UK are in the magnitude of a 20\% gender wage gap (Harkness, 1996; Blackaby et al. 1997; Lissenburgh, 2000, Swaffield, 2000). Part of the gap can be explained by differences in the observed characteristics of both genders, such as education and experience but even accounting for these factors affecting productivity a substantial gap is left unexplained. This unexplained gap stems from either non-observed productivity differential or employer discrimination.

Becker (1971) articulates a model in which the employer's utility is a function of the workforce composition rather than purely due to profit maximisation. Employers with a taste for discrimination would pay men a premium in order to avoid hiring women. Similarly, employers with a taste for discrimination may not promote women to more senior positions ${ }^{1}$. This glass ceiling for women means that discriminating employers would not maximise employees' output and thus forgo profits. In a competitive market, discriminating employers would be driven out of business by profit maximising employers but empirically, the sex ratio of the firm is not linked to profit nor survival (Hellerstein et al, 2002) even so discriminatory behaviours in hiring exist (Goldin and Rouse, 2000) $)^{2}$.

\footnotetext{
${ }^{1}$ The lower promotion of women may not follow from employers' discrimination but from gender differences in non-market opportunities causing women to invest less in the specific human capital required to be promoted (Lazear and Rosen, 1990).

${ }^{2}$ Discriminatory behaviours are typically difficult to observe. Using a unique panel of applicants to jobs at 11 symphonic orchestras in the US and detailed information on the hiring process, the authors find that "blind" auditions, in which the gender of the candidate is not revealed to the jury, result in an increased probability of women obtaining the job.
} 
Discrimination can also stem from fellow workers and customers. Women may then select themselves in less discriminating occupations therefore depressing wages in these specific occupations. Occupational crowding may also generate from social pressure, with women participating in the labour force being or feeling obliged to work in typically female occupations.

Alternative hypotheses competing to explain the gender wage gap are numerous. As women traditionally take career breaks for child rearing reasons, they may choose occupations with flatter wage profile (Polachek, 1981). As, the wage gap does not increase through time for full-time individuals permanently employed, the wage gap may stem from lower starting wage and/or career breaks, which prevent women from climbing the job ladder (Manning and Robinson, 1999). Also women may also be more likely to work in the public sector for beliefs that equal opportunity policies would be better implemented (Dickens, 1993) or due to a belief that public sector offers better family friendly policies. More generally, women may trade off wages for characteristics of the job improving their family life (shorter commuting, hours flexibility), thus the gender wage gap can be seen as a compensating differential (Killingsworth, 1987). Additionally, women may be constrained in their job search by their partner's decision and thus not reach the optimal match.

To summarise, men and women are not perfect substitute, this unobserved heterogeneity accounts for as much as $50 \%$ of the gender wage gap (Polachek and Kim, 1994). The heterogeneity of workers of both genders can be traced in differences in educational choice (Polachek and Kim, 1994, Chevalier, 2002) and career expectations (Swaffield, 2000, Vella, 1997).

This empirical analysis uses a unique dataset that allows controlling for a large set of characteristics usually unobserved such as motivation. This data set of young UK graduates; a homogenous population that has been on the labour market for a maximum of 42 months, 
limits participation selection, career interruption, glass ceiling and discouragement workers phenomena. Furthermore, the dataset includes detailed education variables such as grade and subject as well as career history. The main advantage of this dataset is to include twenty variables on career and life expectations, thus offering a unique opportunity to unveil some other components of gender's heterogeneity. The gender wage gap is then decomposed including subject of degree, occupational choice and motivations to estimate the relative effects of these variables at explaining the pay gap.

The paper is organised as follow: the next section explains the reviews various decomposition techniques. Section 3 reviews the literature on the effect of subject choices, occupational choices and character traits on wages, and when possible relates it to gender differences in these variables. The data used for the decomposition is described in section 4 and the results of the decomposition are presented in section 5 .

\section{II methodology}

As in the bulk of the literature, we estimate separately for both genders a log wage equation.

$$
\ln w_{i g}=X_{i g} \beta_{g}+\varepsilon_{i g} \quad \mathrm{~g}=\mathrm{m}, \mathrm{f}
$$

The left-hand side of (1) is the log wage of individual $\mathrm{i}$ of gender $\mathrm{g}$, the determinants of which are included in a vector $X_{i g} . \beta_{g}$ is the estimated vector of the returns to gender mean characteristics and $\varepsilon_{\mathrm{ig}}$ is an individual error term. The average gender gap in earning is decomposed between the mean difference in observed characteristics and the difference in the returns to these characteristics.

$$
\Delta=\overline{\ln w_{m}}-\overline{\ln w_{f}}=\left(\overline{X_{m}}-\overline{X_{f}}\right) \beta_{g}+\left(\beta_{m}-\beta_{f}\right) \overline{X_{1-g}}
$$

(2) can be expressed at the mean characteristics of men (m) or women (f). The first term of

(2) is the part of the gender pay gap that can be explained by the differences in the observed 
characteristics of both groups. The second part, the unexplained component, is the portion of the gap that is due to differences in the returns to characteristics between the two groups. If all the determinants of earnings were observed in (2) this will be equivalent to a discrimination effect. As typically not all the determinants of (2) are observable, we will refer to this term as the unexplained component of the gender wage gap. The choice of a reference group to decompose (2) is not innocuous but since neither wage function $\left(\beta_{g}\right)$ would exist in the absence of discrimination, both choices lead to biased estimates of the explained wage gap. Rather than giving a weight of one to the wage function of one group and zero to the other, Cotton (1988) advocated the use of population weight. The wage function that would prevail in a post-discrimination world $\left(\beta^{*}\right)$ can be approximated as a weighted average of the one currently faced by both genders. Thus, the gap can be expressed into three components:

$$
\begin{aligned}
& \Delta=\left(\overline{X_{m}}-\overline{X_{f}}\right) \beta^{*}+\left(\beta_{m}-\beta^{*}\right) \overline{X_{m}}+\left(\beta^{*}-\beta_{f}\right) \overline{X_{f}} \\
& \text { where, } \beta^{*}=\frac{n_{f}}{N} \beta_{f}+\frac{n_{m}}{N} \beta_{m}
\end{aligned}
$$

The first term in (3) is the explained wage gap measured at the non-discrimination wage function. The unexplained component is divided into two parts: the advantage of the men (extra returns compared to what should be observed in a non-discriminatory world) and the disadvantage of women. Neumark (1988) refutes that the wage function in the absence of discrimination would simply be the weighted average of the men and women current functions. Instead, he advocates the use of pooled estimates to approximate $\beta^{*}$. The final decomposition remains similar to the one presented in (3). Neumark's decomposition is used throughout this paper.

The decomposition of the gap between explained and unexplained component is complemented by an analysis of the fraction of the wage gap that can be attributed to differences in returns. Starting from the first term in (2): 


$$
\Delta_{g}=\left(\bar{X}_{m}-\bar{X}_{f}\right) \beta_{g}
$$

$\Delta_{g}$ reflects the increase in female wages estimated at the price of gender $g$ if the endowment differential were eliminated. However, Brown and Corcoran (1997) point out that such a measure would not be independent of the metrics used. For example, a dummy variable such as ethnicity would have opposite effect on the wage differential when the base category is fixed at white rather than non-white. To avoid these metric problems, Brown and Corcoran advocates the use of an alternative defined as:

$$
\Delta=\Delta_{m}-\Delta_{f}
$$

The interpretation of $\Delta$ is simply that an elimination of the endowment differential for variable $\mathrm{X}$, would lead to a pay increase of $\Delta$ if estimated at the male prices rather than the female prices. $\Delta$ is small if either the difference in endowment is small or the differences in the returns are small, thus $\Delta$ provides a measure of the contribution of a specific variable to the wage gap, incorporating differences in endowment and returns.

\section{III literature}

\subsection{Subject effects}

The human capital theory suggests that individuals invest in their education until the current value of the future earnings associated with the level $\mathrm{s}$ of education equals the cost of that year of education. The cost can be split between the direct cost of education (fees) and the forgone earnings (wages that could have been obtained during that extra year of education). Formally, the optimal schooling decision is the value of S for which the net present value of the steam of income (w) associated with educational level S equals the total cost of an extra year of education (cost of education, C plus forgone earnings, w(S-1)): 


$$
\sum_{t=s+1}^{T} \frac{w(s)-w(s-1)}{(1+r(s))^{t}}=w(s-1)+c(s)
$$

where $\mathrm{r}(\mathrm{s})$ is the discount rate of an individual with education level $\mathrm{S}$ and $\mathrm{T}$ is the expected working life of the individual. This simple model can be modified to explain the choice of a university major, where the probability of success in each subject is included (Montmarquette et al, 2002). These authors note that for men but not for women, the choice of subject is based on the financial returns of this decision. Men take more risks of failing for higher returns while women are more risk adverse, and chose the subject with the greatest prospects of success and possibly for which they have the highest affinity. These behaviours are consistent with higher earnings for men but also more educational regret when accounting for wages (Chevalier, 2002).

While participation to higher education is nearly at parity for the cohort of interest, there are marked differences in the choice of subjects (see Table 1). Based on the university records, students segregate themselves by gender with scientific subjects being male dominated while Arts/Humanities based subjects have a higher female participation. A measure of segregation, such as the Duncan index suggests that around 30\% of women would have to change their subjects to make the distribution of majors identical between both genders ${ }^{3}$. Despite large changes in attendance to higher education and to the gender mix, there is no evidence that subject segregation by gender has been reduced over the 1985-95 period, as the indices of segregation are of similar magnitude. Subjects most popular with women are associated with lower grades (McNabb et al., 2002), higher risk of unemployment and over-education and lower average pay in general (Chevalier, 2002).

\footnotetext{
${ }^{3}$ The Duncan index (Duncan and Duncan, 1955) is simply defined as $D=1 / 2 * \sum_{i=1}^{k}\left|p_{m i}-p_{f i}\right|$, where $\mathrm{p}_{\mathrm{mi}}$ $\left(p_{\mathrm{fi}}\right)$ is the share of the male (female) sample observed in subject $i$, and $k$ is the number of subjects.
} 
[Table 1 around here]

Subject choice impacts on earnings directly and indirectly. A small literature on the returns to higher education by subject exists. For the UK specifically, large variation in the returns by subjects is found with scientific majors usually at the top of the distribution and Arts, Languages and Social Sciences towards the bottom (Chevalier et al., 2002, for a review). For all majors, the returns are higher for women than for men and the differences are the largest for Arts and Education graduates. This does not indicate that female graduates earn more than their male counterparts, but mostly reflects that higher education reduces the gender wage gap.

Brown and Corcoran (1997) for the US, Baraka (1999) for Taiwan and Machin and Puhani (2002) for the UK and Germany have specifically estimated the effect of university major on the gender wage gap. Including subject of graduation typically increases the explained component of the gender wage gap by 6 to 17 percentage points and a staggering $35 \%$ for Brown and Corcoran using the NLS72. Machin and Puhani also test whether subject aggregation matters. With the most detailed subject specification (124 and 71 subjects respectively for the UK and Germany), the increased in the part of the explained wage gap due to subject dummies doubles for the UK while the increase is less substantial in Germany ${ }^{4}$.

\subsection{Occupation effects}

For discrimination, socialisation or taste reasons, women choose different type of occupation and sector of activity. Figure 1 plots the proportion of graduates employed in the public

\footnotetext{
${ }^{4}$ The high disaggregation of subjects may bias the results of the decomposition. For subjects with a large gender imbalance and a small number of observations, the subject estimates in the wage equation for the "minority" gender are imprecise and are multiply by the mean gender difference in participation (which is large) in order to calculate the explained component of the differential.
} 
sector, six months after graduation, in $1993^{5}$. Almost all graduates from Medicine and to a lower extent from Education work in the public sector. What is more remarkable is the statistically significant difference in the proportion working in the public sector by gender; $37 \%$ of female graduates work in the public sector 6 months after graduations but only $23 \%$ of males do so. This gender gap in public sector employment is observed for most subjects and the highest differences are found for graduates from studies allied to Medicine, Education, Librarianship and Social Sciences. The preference for working in the public sector and thus encountering a pay penalty between $7 \%$ and $12 \%$ (Chevalier et al., 2002) may be due to character traits, or in the case of women, a belief that the public sector provides a more equal and family friendly environment (Dickens, 1993).

Socialisation affects occupational behaviour in three ways (Corcoran and Courant, 1985). First, socialisation may affect character traits directly, so that women are more caring and altruistic than men. Second, children may internalised sex-roles and reproduce them in their occupational choices; third, socialisation influences the values attached to activities. Hence it is observed that women's participation to the labour force is concentrated in a limited number of occupations. This concentration, which could also be due to discrimination, has a negative effect on wages (Backer and Fortin, 1999). The penalty for working in a female dominated occupation is larger for women than men (Brown and Corcoran, 1997) but this finding is not universal and others reckon that wages are lower for the minority gender in a given occupation.

\section{3 character choice}

Recently, economists have integrated character traits to determinants of wages. Leadership, motivation and self-esteem but also aggression, beauty and cleanness are among the traits

\footnotetext{
${ }^{5}$ This graph is based on the First Destination Survey, a survey of the universe of students conducted 6 months after graduation.
} 
positively correlated with wages (see Bowles et al., 2001, for a survey). Even for traits that appear trivial, the effect on wages can be quite large. For example, increasing beauty from below average to above average increases the hourly wage of male American lawyers by $14 \%$ (Hamermesh and Biddle, 1994). The impact of these characteristics also differ by gender; in high occupation status, Osborne (2001) using the UK National Child Development Study estimates that a one standard deviation change in aggression increases the earnings of men by $20 \%$ but reduces those of females by $14 \%$. Due to socialisation, character traits differ by gender, with women being more altruistic and men selfish and competitive. However, the main attitudinal difference between men and women concern the childrearing role.

Most of the literature on the gender wage gap has stressed the importance of career interruptions and family responsibilities, but only a few have incorporated a measure of the attachment to the labour force. Vella (1994) use an attitude index to divide the population of young Australian between modern and traditional relative to the role of women and report a large effect of modernity on female educational attainment (moderns are 10 percentage points more likely to attend university). Furthermore, it is the nature of the investment and not its quantity that generates lower returns for individuals with traditional attitudes. Swaffield (2000) builds a similar index for the British working population and conclude that work motivation is a significant determinant of wages and since women are less career oriented, the omission of motivation reduces the explained gender wage gap

\section{Data}

The empirical evidence is based on a recent cohort of UK graduates thus limiting the effect of selection in the labour market, disappointment due to discrimination and glass ceiling. The data originates from a postal survey of individuals who graduated in June 1996 from a sample of 33 UK tertiary education institutions (Ellias et al., 1998). The individuals were contacted 
by their university Alumni and the survey includes a complete history of the 42 months elapsed since graduating. Mature students and individuals with disabilities are excluded and only individuals graduating with a first degree are kept, leaving a sample of 7,640 graduates. The survey includes a wealth of information on university attainment and current employment. One of the drawbacks of the survey is that the annual gross wage is reported in category, and more importantly, the number of hours worked per week is not reported. Since, women work on average less than men, the gender wage gap using annual wage is biased upward. To limit this bias, only full-time employees are kept; this proportion is identical for men and women $(85 \%)$ limiting the effect of selection on estimated wages. Finally, we drop individuals who did not report their current wage or occupation, not living in the UK and with missing values on the variables of interest; this leaves us with a sample of 5187 graduates.

This dataset is unique as it includes 20 questions on character traits, motivation and expectations, divided into two sets, with answers coded on a 5 points scale from very important (1) to unimportant $(5)^{6}$. The first set deals with job values while the second set contains career expectations. The distributions of answers to these questions are reported separately by gender in Tables $2 \mathrm{~A}$ and $2 \mathrm{~B}$. Apart from the importance of status and respect, leisure and concern with current affair, the long-term values of graduates are gender differentiated. Men are more likely to state that career development and financial are very important long-term values, while women put forwards, personal development, job satisfaction, being valued by employer and doing a socially useful job. On the latter the gender difference is large, $50 \%$ of women agree that a socially useful job is important or very important, but only $33 \%$ of men make the same statement and $35 \%$ of them think that it is not important or unimportant. This difference in the type of jobs wanted explains the high feminisation of jobs such as teacher and nurse. Women are also more likely to be concerned

\footnotetext{
${ }^{6}$ In order to avoid dropping another $9 \%$ of the sample, we recoded individuals with a missing statement to not sure. Xxx redo analysis with and without, does it make any change
} 
by local issues and ecology. The gender differences in long-term values are rather consistent with stereotypes with men being less altruistic than women.

This is backed up with the findings on career expectations, with men being 10 percentage points more likely to strongly agree that they are extremely ambitious. The only other gender differences in career expectations concern career breaks. Despite improvements in family friendly policies, $66 \%$ of women still expect to take breaks for family reasons (agree somewhat or strongly) and only $17 \%$ expect their partner to do so. Men favours this repartition of tasks with $40 \%$ of them expecting their partner to take a career break for family reasons and only $12 \%$ of them expecting to do it themselves. Furthermore, the reintegration to the labour market may not be a priority with a third of women not expecting to work until retirement. Indices summarising the information on these statements are also constructed ${ }^{7}$. The two indices are then normalised. Surprisingly, the two indices are not correlated $(-0.05)$. All other relevant variables are reported in Table 3. The distribution of wages is reported in Figure 2. The mean pay in 1998 is $£ 18,500$ for women and $£ 21,200$ for men, but these mean characteristics hide differences in the distribution of pay between genders. The distribution is shifted to the left for women

\section{$V$ results}

Traditionally, the pay gap is decomposed between the differences in observed characteristics between men and women and the differences in the returns to characteristics by gender; the latter terms reflecting the unexplained part of the differential. A large share of the wage gap is usually left unexplained. We argue that gender differences in the educational choices (majors) career choices (occupation) and expectations (character traits), typically not included

\footnotetext{
${ }^{7}$ The indices are constructed by allocating points to the answers, 5 for strongly agree to 1 for strongly disagree, after adjusting the questions for career orientations, thus personal development, job satisfaction, socially useful job, concern in local issue, ecology and current affairs were inverted. Similarly, the statements concerning fulfilment from work, I work to live and expect to take career breaks, that are negative values as far as career are concerned were inverted to calculate the career expectations index.
} 
in the decomposition, should account for differences in taste and socialization, therefore identifying the unexplained component of the wage gap. The remaining unexplained component may then be interpreted as resulting from some form of discrimination, if we believe that all relevant controls have been included. However, educational and occupational choices as well as character traits may themselves be the results of discrimination and socialisation, so it is more appropriate to keep the terminology of explained and unexplained components.

Various variables determine the wages of individuals independently from their gender; these variables are typically age, work experience, education and other personal or job characteristics. Since, the population of interest in this study is rather homogenous, the variation in wages is limited and the raw gender gap in yearly gross wage is "only" $12.4 \%$. This gap can be decomposed between a component due to gender differences in the mean observed characteristics and two components reflecting the disadvantage of women and the advantage of men compared to an "average" individual in a non-discriminating world.

The base model is estimated with a parsimonious specification including a quadratic in labour market experience, and dummies for graduating after the age of 24 , being white and region of residence. Due to the specificity of the population, this base model explains only $10 \%$ of the wage gap suggesting that in the early months of graduates' careers, the variation in the endowment in these observed variables is limited.

As reported in Table 4, the second specification includes various measures of educational achievement such as A-level score, degree results, institution type and post-graduate achievements which broadly speaking are correlated with ability. These variables account for $60 \%$ of the explained wage gap and their inclusion double the proportion of the gender wage gap that can be explained by differences in endowment to $20 \%$. However, the inclusion of controls for the subject of graduations (model 2') eliminates the explanatory powers of these 
educational variables. Thus, the wage gap for graduates does not originate in differences in educational attainment but from subject segregation with women graduating from subjects with lower financial returns. Model 2 findings stems from the differences in A-level achievements, probability of gaining first honours and institution type by subjects, rather than gender differences in these characteristics. Subject of graduations alone account for almost $90 \%$ of the explained wage gap, raising concern on the conclusions of other empirical work where these variables were not included. The origin of this segregation can be found in socialisation, discrimination and character differences.

In order to test for discrimination at the work place, the base model is enriched with characteristics of the work place (size, sector), type of contract and feminisation ${ }^{8}$ of the occupation. These variables account for $90 \%$ of the explained wage gap, which rises to $56 \%$ of the raw gap. Typically, differences in firm type, contracts and feminisation by gender are large. It can be argued that these variations stem from employers discrimination or social pressure and therefore does not allow any conclusion on employers' discrimination.

Specification 3' also adds dummies for occupational group. This follows from arguments on the glass ceiling and the concentration of women in jobs at the bottom of the socio-economic ladder and their lower promotions to high paying jobs. Since, the observed graduates have been in the labour market for 42 months, differences in promotions are likely to be reduced and the current positions occupied mostly reflects the point of entry. The inclusion of these variables has no (even negative) effect on the explained wage gap, suggesting that early on in their career, there is no gender difference in the occupational attainment of graduates. This result could also stem from the broad definition of social group used here (Kidd and Shannon, 1996).

\footnotetext{
${ }^{8}$ This is constructed at the 2-digit occupational code level from the 1996 Labour Force Survey, quarter 3, for all employees aged 16-59. Backer and Fortin (1999) state that results on the effect of feminisation on the gender wage gap are sensitive to the level of aggregation of the feminisation variable. Two-digit level is the most detailed level of aggregation attainable with the graduate dataset.
} 
Models 4 and 4' extend the base model by adding information on the character of the individuals, respectively, the character scores or the 20 individuals character traits. Surprisingly, these two models lead to different conclusions. Normalised scores have no effect on the model and do not reduce the gender wage gap, while the model including all character traits explains $64 \%$ of the raw gap; job expectations account for $52 \%$ of the explained gap and career expectations for another 39\%. Thus, character traits and expectations differences between genders are a main determinant of the wage gap. The origin of these differences are difficult to determine, but as stated by Corcoran and Courant (1985) “socialization may directly affect workers' skills and personality traits (p275)", thus policies reducing the gender wage gap could only be effective in the long-run after attitudes have been adjusted, which is consistent with the observations that after the rapid reduction of the wage gap when equal opportunity laws were introduced, progress have been much slower.

Model 5 and 5 ' include all the covariates. Model 5 explains $58 \%$ of the wage gap; most come from the job specific characteristics. The effect of the education variables, which in model 2 accounted for $60 \%$ of the explained wage gap, is halved. The full model (5') explains $84 \%$ of the wage gap, with the advantage of men and disadvantage of women being almost equal. Differences in job and career expectations account for the bulk of the explained gap but the introduction of these expectation variables does not eliminate the effect of subject segregation and job characteristics. Socialisation affects the educational and occupational choices of young graduates as well as their job and career expectations, but these variables are not perfectly correlated and should all be included in a wage gap analysis.

In order to assess in more details the factors responsible for the wage gap, we now reports the wage estimates for our preferred specification (5'). Due to the young age of the population the experience profile is inverted for the first 18 months. Even accounting for labour market experience, workers aged 26-29 earn 6\% more than younger graduates. As expected graduates 
living in the tighter and more costly labour markets are paid a premium and there is no ethnic discrimination. For these base-model variables no gender variation in the returns is found, but since the men have $8 \%$ more month of work experience than women (Table 3), an equalisation would have some effect on the gender wage gap (Delta is reported in Table 5, using (5). The sum of the $\Delta$ for the base model is nil; these variables have no effect on the gender wage gap of graduates.

The type of institution attended has a substantial effect on returns for both genders, older institutions providing either more able graduates or a network effect. The premium to attending an older institution rather than a 60's university is larger for men. Other signal of ability also provide important returns; a first class honour increases wages by 5 to $12 \%$ compare to other grades and the premium compared to an upper second honour is significantly larger for women. Since women are also more likely to obtain a $2 / 1$, a levelling to the men's standard would penalise women. Even if variations in the mean educational characteristics and their returns are apparent, most education variables have insignificant or negative $\Delta$ thus their global impact on the gender wage gap is negative $(\Delta=-0.003)$.

Arts graduates have the lowest returns to tertiary education, and are penalised by $19 \%$ compared to female graduates in Maths or Medicine; the wage gap penalty for graduating from arts rather than those subjects is even larger for men. Added to the gender variation in the choice of degree, the gender differences in returns means that these variables contribute to the gender wage gap; Maths, Medicine and Engineering all have $\Delta$ around .005 .

Women are more likely to work in small firms, possibly for convenience reasons, since as small firms are more evenly spread, the commuting to work is smaller. Another view is that women are constrained in their job search by the match realised by their partner. It is however surprising that these differences are observed at an early career point. Alternatively, 
differences in confidence and ambitions may explain the gender differences in firm choice. It is well known that smaller firms pay lower wages, but the spread is less important for women. Female graduates work in an occupation with $50 \%$ more female workers and the wage penalty associated with working in a female occupation is twice as large as for men. Thus, the wage penalty associated with working in a female dominated occupation is larger for women, as in Brown and Corcoran, and the $\Delta$ reaches -0.013 . Women are as likely as men to get a permanent contract $(80 \%)$ but men's returns to a permanent contract are $70 \%$ higher. In contradiction with the double imbalance whereby pay in the public sector is higher at low level of the occupational ladder but less at high level, we find that after accounting for education and various career expectations, graduates in the public sector are better paid than those in the private sector. This result could stem from differences in the earning profiles in the two sectors, with flatter profiles and higher starting salaries being found in the public sector. Women are twice as likely to work in the public sector than men, since typical female graduate occupations, such as nurses and teachers, are almost exclusively found in the public sector. Differences in the job characteristics and the returns to these characteristics by gender are important, and the $\Delta$ for these variables reaches $(-0.007)$.

At the large level of aggregation used, the distributions of occupations are rather similar for both genders, but the returns do vary, thus these variables contribute to the gap. As seen in Tables $2 \mathrm{~A}$ and $2 \mathrm{~B}$, large variations in the expectations of men and women are observed. These measures of motivations are also rewarded differently on the labour market. Women who are motivated by financial rewards, status, international experience and claim to be ambitious are rewarded while those favouring career development and surprisingly who expect to work until retirement suffer from a pay penalty. Men concern with ecological issue and doing a socially useful job, two female traits, are penalised, while these character traits had no significant effect on female wages. This could reflect that men with non-traditional 
motivation are discriminated against. Like women, men who are motivated by financial rewards, international experience and claim to be ambitious are paid more, but the returns are somewhat larger for men. Furthermore, those with a traditional attitude regarding the family (expecting their partner to take a break in her career for family reasons) are also paid 3\% more. The data does not allow us to differentiate between a reward for being traditionalist and reverse causality, where richer men can support their family and expect their partner to have a traditional role. These results on attitude towards family roles are in contradiction with Vella (1994) who reports that modern attitude affects women's wages positively and has no effect on male wages. Differences in attitudes towards family role are the main two determinants of the gender wage gap.

\section{Conclusion}

Even looking at a homogenous population of recent UK graduates a wage gap of $12 \%$ is found. The dataset is rich of covariates usually not available in this type of studies, which allows us to control not only for typical human capital variables but also for the subject of university study, occupation and character traits. These character traits also measure attitudes towards childrearing. We found significant gender differences in the subject of graduation, the sector of employment and feminisation of the job, but also conforming to the stereotypes, women are more altruistic and men more selfish and career driven. Conform to socialisation and self-selection models of the gender wage gap, women invest in a different type of human capital, are more likely to work in the public sector and female dominated occupations. These differences remain even when accounting for motivation and expectations. With this extended specification, $84 \%$ of the gender wage gap can be explained, so it would appear that discrimination is limited (at least for this population of recent graduates). However, the 
differences in subject and occupation choice or characters may be due to some discrimination and social pressure.

A large proportion of the wage gap originates from attitudes towards childrearing; $2 / 3^{\text {rd }}$ of women agree that they expect to take career breaks for family reasons while only $12 \%$ of men do so. Men also expect their partner to sacrifice her career for childrearing responsibilities. Since change in attitude may be slow, the gender wage gap is likely to persist. Policies to eliminate it should reduce the disturbance of childrearing duties on women and improve family friendliness of firms as well as access to childcare services. Such policies would have a direct effect as well as a long-term effect on socialisation leading to a reduction in the gender differences in educational, occupational choices, character traits and career expectations. 


\section{References:}

Altonji J. and R. Blank, 1999, Race and Gender in the labor market, in Handbook of Labor Economics, Vol 3C, O. Ashenfelter and D.Card (eds), North-Holland

Backer M. and N. Fortin, 1999, Occupational gender composition and wages in Canada: 1987-88, National Bureau of Economic Research, WP 7371

Baraka J., 1999, Does type of degree explains Taiwan's gender gap, Research in Development Studies, Princeton University, Mimeo

Becker G. (1971) Economics of discrimination, Chicago: The University of Chicago Press

Blackaby D., K. Clark, D. Leslie and P. Murphy, 1997, The distribution of male and female earnings 1973-91: Evidence for Britain, Oxford Economic Papers, 49, 256-272

Blau F. and L. Kahn, 2000, Gender differences in pay, Journal of Economic Perspective, 14, 75-99

Bowles S., H. Gintis and M. Osborne, 2001, The determinants of earnings: A behavioural approach, Journal of Economic Literature, 39, 1137-1176

Brown C. and M. Corcoran, 1997, Sex-based differences in school content and the malefemale wage gap, Journal of Human Resources, 15, 431-465

Chevalier A., 2002, Education, motivation and pay of UK graduates; Is it different for girls?, Institute for the Study of Social Change, UCD, Mimeo

Chevalier A., G. Conlon, F. Galindo-Rueda and S.McNally, 2002a, The returns to higher education teaching, Department for Education and Skill, Research Report

Chevalier A., P. Dolton, G. Makepeace and S. McIntosh, 2002b, Relative pay in the public and private sector, Her Majesty Treasury, Research Report

Corcoran M and P. Courant, 1985, Sex role socialization and labor market outcomes, American Economic Review, 75, 275-278 
Cotton J., 1988, On the decomposition of wage differentials, Review of Economics and Statistics, 70, 236-243

Dickens 93

Duncan O. and B. Duncan, 1955, A methodological analysis of segregation index, American Sociological Review, 20, 210-217

Elias P., A. McKnight, J. Pitcher, K. Purcell and C. Simm, 1999, Moving on: Graduate careers three years after graduation, CSU/DfEE

Goldin C. and C. Rouse (2000) Orchestrating impartiality: the impact of "blind" auditions on female musicians, American Economics Review, 90, 715-740

Hamermesh D. and J. Biddle, 1994, Beauty and the labor market, American Economic Review, 84, 1174-94

Harkness S., 1996, The gender earnings gap: evidence from the UK, Fiscal Studies, 17, 1-36

Hellerstein J., D. Neumark and K. Troske (2002) Market forces and discrimination, Journal of Human Resources, 37, 353-380

Kidd M. and Shannon M., 1996, Does the level of occupational aggregation affect estimates of the gender wage gap?, Industrial and labor relations review, 49, 317-329

Killingsworth M., 1987 Heterogeneous preferences, compensating differentials and comparable worth, Quarterly Journal of Economics, 102, 727-742

Lazear E. and S. Rosen, 1990, Male-female wage differentials in job ladders, Journal of Labor Economics, 8,S106-S123

Lissenburgh S., 2000, Gender discrimination in the labour market, Policy Studies Institute, RP 3, London

Machin S. and P. Puhani, 2002, Subject of degree and the gender wage differential: Evidence from the UK and Germany, Department of Economics, IZA, 
Manning A. and H. Robinson, 1999, "Something in the way she moves", Centre for Economic Performance, DP 389, LSE

McNabb R., S. Pal and P. Sloane, 2002, Gender differences in educational attainment: The case of university students in England and Wales, Economica, 69, 481-503

Montmarquette C., K. Cannings and S. Mahseredjian, 2002, How do young people choose college major? Economics of Education Review (forthcoming)

Neumark, D. (1988). Employers' Discriminatory Behavior and the Estimation of Wage Discrimination, Journal of Human Resources, 23, 279-295

Osborne M., 2001, The economic significance of personality: differential rewards by sex and status, Towson University, mimeo

Polachek S., 1981, Occupational self-selection: A human capital approach to sex differences in occupational structure, Review of Economics and Statistics, 60-69

Polachek S. and Kim M.K., 1995, Panel estimates of the gender earnings gap, Journal of Econometrics, 61, 23-42

Swaffield J., 2000, Gender Motivation, experience and wages, Centre for Economic Performance, London School of Economics, DP 417

Vella F., 1994, Gender roles and human capital investment: The relationship between traditional attitudes and female labour market performance, Economica, 61, 191-211

Weichselbaumer D. and R. Winter-Ebmer, 2001, The effects of markets, politics and society on the gender wage differential: A meta-analysis, University of Linz, Mimeo 
Table 1: Distribution of subject by gender.

\begin{tabular}{lccc|ccc|ccc}
\hline & \multicolumn{3}{c|}{$1985 / 86$} & \multicolumn{3}{c|}{$1990 / 91$} & \multicolumn{3}{c}{$1993 / 94$} \\
\hline Year & Male & Female & Diff & Male & Female & Diff & Male & Female & Diff \\
\hline \hline Medicine and dentistry & 7.03 & 6.88 & 0.15 & 6.04 & 6.45 & 0.41 & 5.33 & 5.51 & 0.18 \\
Studies allied to medicine & 1.51 & 4.35 & 2.84 & 1.65 & 4.67 & 3.02 & 1.76 & 5.29 & 3.54 \\
Biological sciences & 6.04 & 9.80 & 3.76 & 6.20 & 10.02 & 3.82 & 6.45 & 10.70 & 4.25 \\
Veterinary science, agriculture and related studies & 1.95 & 1.90 & 0.05 & 1.43 & 1.51 & 0.08 & 1.13 & 1.41 & 0.29 \\
Physical sciences & 13.03 & 5.83 & 7.20 & 11.55 & 5.76 & 5.79 & 11.46 & 6.35 & 5.10 \\
Mathematical sciences & 8.19 & 4.33 & 3.86 & 9.35 & 3.92 & 5.43 & 9.28 & 3.61 & 5.66 \\
Engineering and technology & 18.64 & 2.25 & 16.38 & 17.93 & 3.07 & 14.86 & 16.99 & 3.34 & 13.65 \\
Architecture and related studies & 1.67 & 0.76 & 0.91 & 1.67 & 0.67 & 0.99 & 1.98 & 0.63 & 1.35 \\
Social sciences & 14.19 & 16.55 & 2.36 & 14.12 & 16.03 & 1.91 & 14.39 & 15.26 & 0.87 \\
Business and financial studies & 4.66 & 3.87 & 0.79 & 5.53 & 4.64 & 0.90 & 5.21 & 4.33 & 0.88 \\
Librarianship and information science & 0.05 & 0.34 & 0.28 & 0.11 & 0.27 & 0.16 & 0.22 & 0.43 & 0.21 \\
Languages and related studies & 5.64 & 18.92 & 13.28 & 5.41 & 16.43 & 11.03 & 6.18 & 16.94 & 10.76 \\
Humanities & 6.23 & 7.89 & 1.66 & 6.42 & 7.31 & 0.89 & 7.27 & 8.40 & 1.14 \\
Creative arts & 1.27 & 2.27 & 1.00 & 1.21 & 2.29 & 1.08 & 1.18 & 2.24 & 1.06 \\
Education & 0.57 & 2.62 & 2.05 & 0.76 & 3.18 & 2.41 & 0.69 & 3.10 & 2.41 \\
Multi-disciplinary studies & 9.31 & 11.44 & 2.13 & 10.62 & 13.79 & 3.17 & 10.48 & 12.42 & 1.94 \\
Total & 100 & 100 & & 100 & 100 & & 100 & 100 & \\
Duncan index & & & 29.36 & & & 27.97 & & & 26.649 \\
\hline
\end{tabular}

Note: Source First Destination Survey 


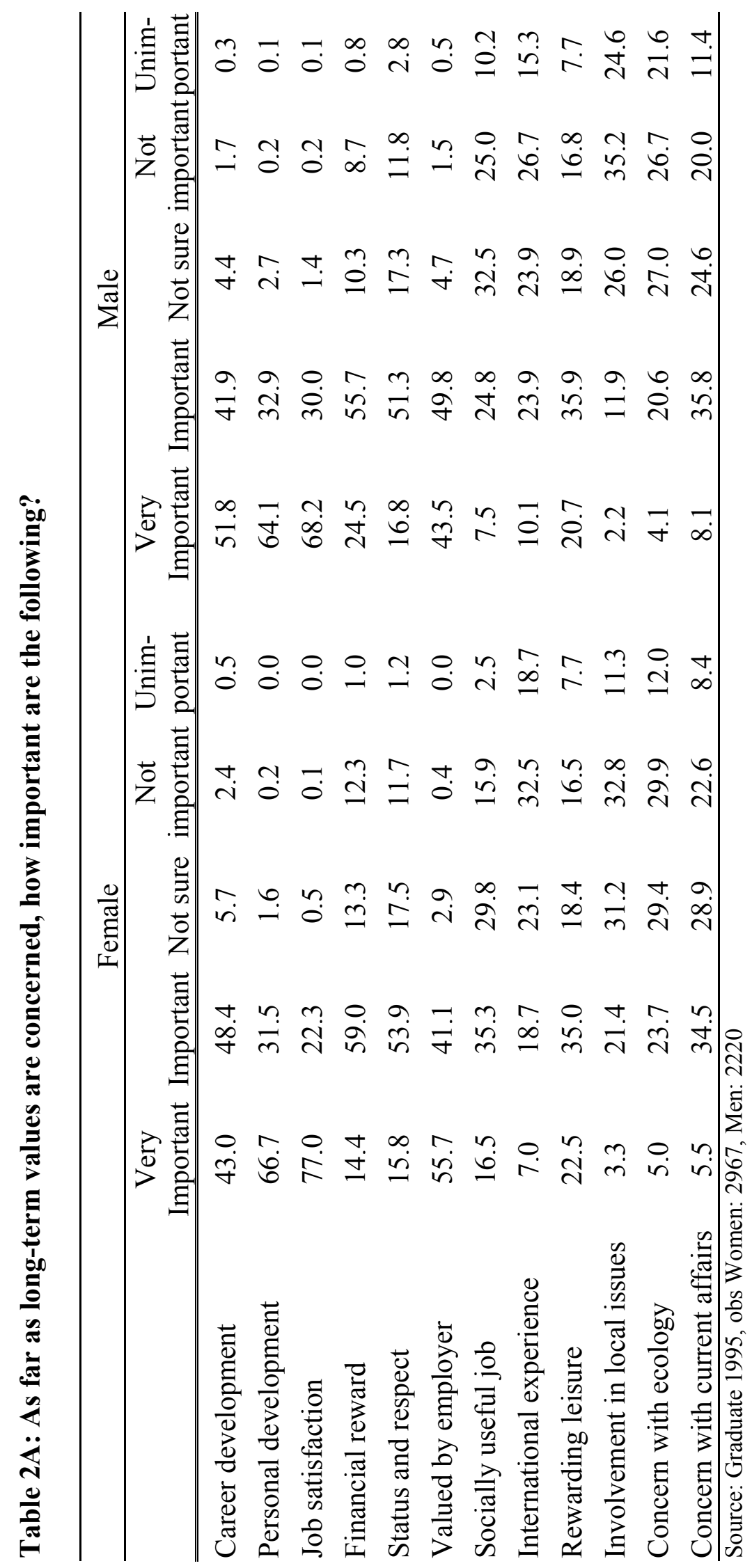




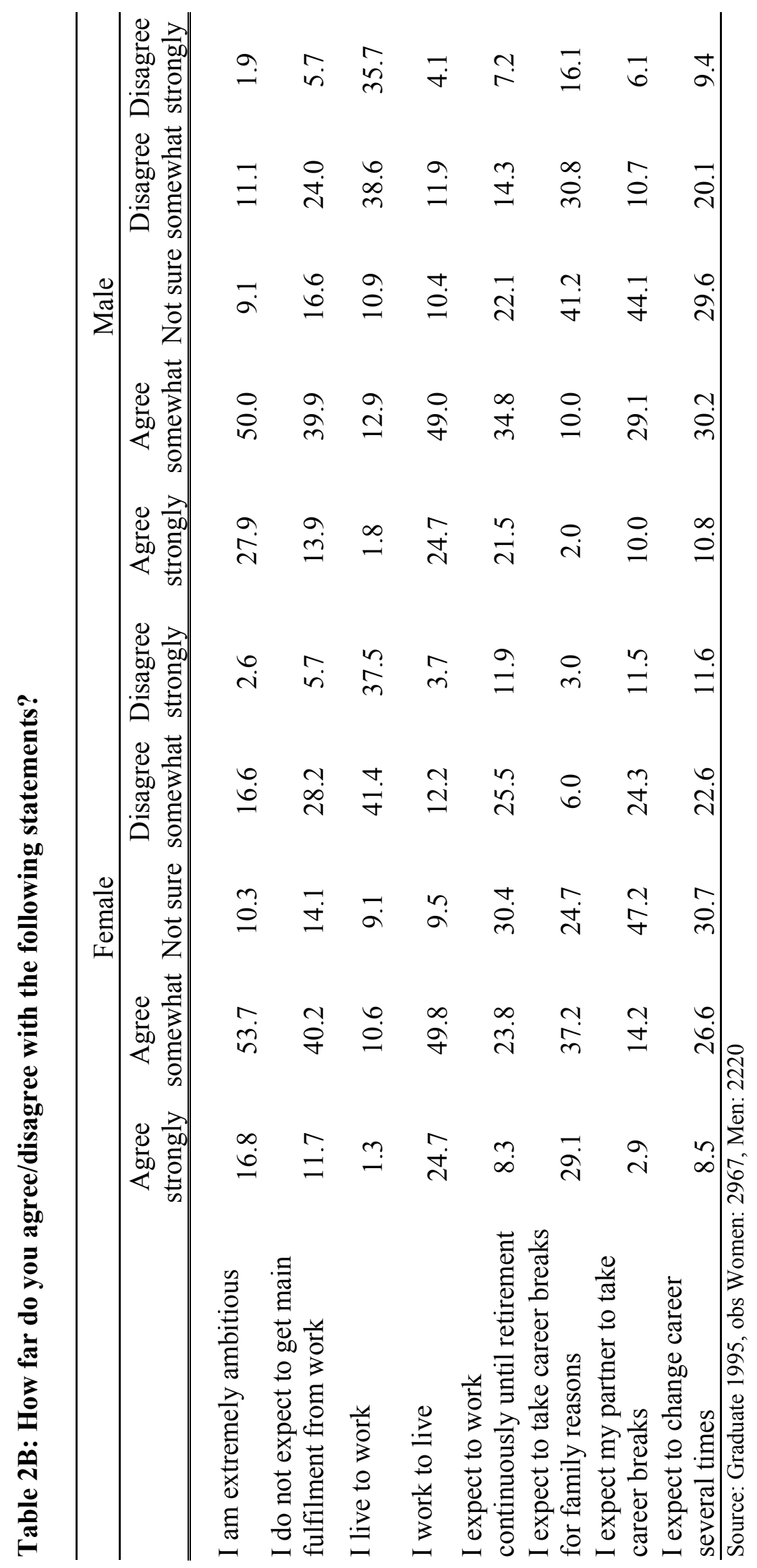


Table 3: Summary statistics- Mean (standard deviation)

\begin{tabular}{|c|c|c|c|c|c|c|c|}
\hline & Women & Men & All & & Women & Men & All \\
\hline Gross pay & $\begin{array}{c}18477.93 \\
(6112)\end{array}$ & $\begin{array}{c}21210.59 \\
(7668)\end{array}$ & $\begin{array}{c}19647.49 \\
(6953)\end{array}$ & & & & \\
\hline $\begin{array}{l}\text { Education } \\
\text { characteristics }\end{array}$ & & & & Job chracteristics & & & \\
\hline Alevel score & $\begin{array}{c}9.12 \\
(3.81)\end{array}$ & $\begin{array}{c}8.49 \\
(4.38)\end{array}$ & $\begin{array}{c}8.85 \\
(4.08)\end{array}$ & Experience & $\begin{array}{c}16.39 \\
(13.09)\end{array}$ & $\begin{array}{c}18.2 \\
(13.67) 0\end{array}$ & $\begin{array}{c}17.17 \\
(13.37)\end{array}$ \\
\hline No A level & 0.11 & 0.17 & 0.13 & Size $<10$ & 0.05 & 0.04 & 0.05 \\
\hline First-class honours & 0.06 & 0.08 & 0.07 & Size $10-24$ & 0.11 & 0.06 & 0.09 \\
\hline Upper second & 0.52 & 0.44 & 0.49 & Size $25-49$ & 0.10 & 0.07 & 0.09 \\
\hline Second honours & 0.34 & 0.36 & 0.35 & Size $50-249$ & 0.19 & 0.19 & 0.19 \\
\hline Other honours & 0.07 & 0.13 & 0.09 & Size $250-499$ & 0.07 & 0.08 & 0.07 \\
\hline Arts & 0.15 & 0.08 & 0.12 & Size $500+$ & 0.47 & 0.56 & 0.51 \\
\hline Humanities & 0.10 & 0.06 & 0.08 & Manager & 0.23 & 0.24 & 0.23 \\
\hline Languages & 0.07 & 0.02 & 0.05 & Professional & 0.38 & 0.35 & 0.36 \\
\hline Law & 0.04 & 0.04 & 0.04 & $\begin{array}{l}\text { Associate } \\
\text { professional }\end{array}$ & 0.20 & 0.22 & 0.21 \\
\hline Social science & 0.14 & 0.12 & 0.13 & Clerical & 0.14 & 0.09 & 0.12 \\
\hline Math \& computing & 0.04 & 0.10 & 0.07 & Other occupation & 0.06 & 0.10 & 0.07 \\
\hline Natural science & 0.11 & 0.12 & 0.11 & $\begin{array}{l}\% \text { female in } \\
\text { occupation }\end{array}$ & 50.23 & 34.63 & 43.55 \\
\hline Medicine & 0.08 & 0.04 & 0.06 & Permanent contract & 0.81 & 0.83 & 0.82 \\
\hline Engineering & 0.02 & 0.21 & 0.10 & Public sector & 0.27 & 0.13 & 0.21 \\
\hline Business & 0.10 & 0.12 & 0.11 & $\begin{array}{l}\text { Personal } \\
\text { characteristics }\end{array}$ & & & \\
\hline Education & 0.10 & 0.02 & 0.06 & Age 26-29 & 0.37 & 0.41 & 0.39 \\
\hline Other vocational & 0.04 & 0.05 & 0.05 & White & 0.95 & 0.92 & 0.93 \\
\hline Interdisciplinary & 0.02 & 0.02 & 0.02 & Character traits & & & \\
\hline Old university & 0.41 & 0.41 & 0.41 & Job value & -0.02 & 0.02 & 0.00 \\
\hline 60's university & 0.10 & 0.11 & 0.11 & Career expectation & -0.06 & 0.08 & 0.00 \\
\hline 90's university & 0.38 & 0.43 & 0.40 & & & & \\
\hline College of HE & 0.12 & 0.04 & 0.08 & Observation & 2967 & 2220 & 5187 \\
\hline Post Grad certificate & 0.21 & 0.12 & 0.17 & & & & \\
\hline Professional qualification & 0.15 & 0.15 & 0.15 & & & & \\
\hline Master & 0.09 & 0.11 & 0.10 & & & & \\
\hline Ph.D & 0.02 & 0.02 & 0.02 & & & & \\
\hline
\end{tabular}




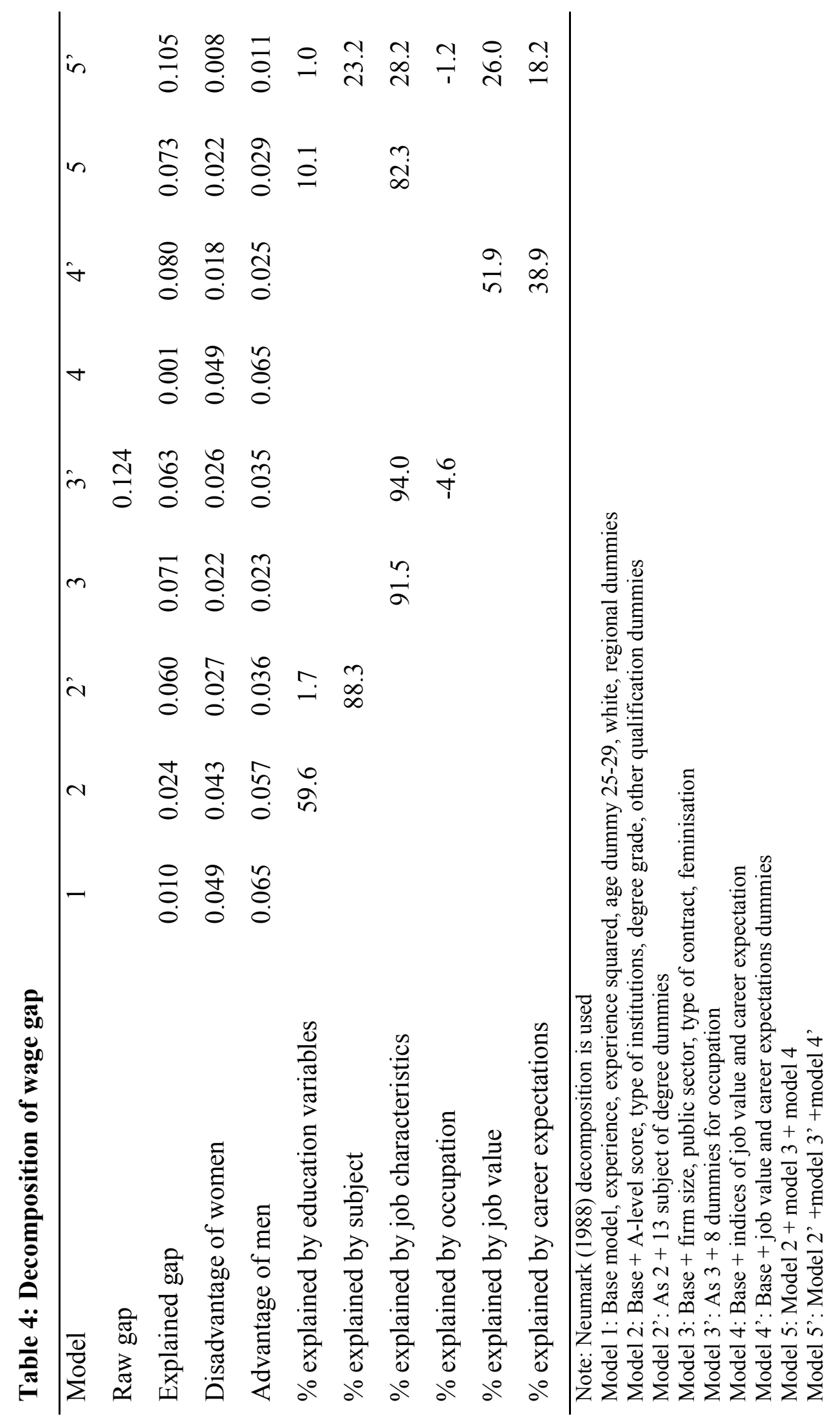



Table 5: Wage functions and Differences in coefficients * differences in means

\begin{tabular}{|c|c|c|c|c|}
\hline & Women & Men & All & Delta \\
\hline Experience & $\begin{array}{l}-0.005 \\
(2.95)\end{array}$ & $\begin{array}{l}-0.008 \\
(3.71)\end{array}$ & $\begin{array}{l}-0.006 \\
(3.68)\end{array}$ & -0.005 \\
\hline Experience $^{2}$ & $\begin{array}{l}0.000 \\
(3.74)\end{array}$ & $\begin{array}{l}0.000 \\
(4.64)\end{array}$ & $\begin{array}{l}0.000 \\
(4.70)\end{array}$ & 0.005 \\
\hline Age 26-29 & $\begin{array}{l}0.061 \\
(5.99)\end{array}$ & $\begin{array}{l}0.064 \\
(4.41)\end{array}$ & $\begin{array}{l}0.061 \\
(7.68)\end{array}$ & 0.000 \\
\hline White & $\begin{array}{l}0.035 \\
(1.57)\end{array}$ & $\begin{array}{l}0.028 \\
(1.41)\end{array}$ & $\begin{array}{l}0.028 \\
(1.74)\end{array}$ & 0.000 \\
\hline A-level & $\begin{array}{l}0.005 \\
(1.77)\end{array}$ & $\begin{array}{l}0.009 \\
(1.92)\end{array}$ & $\begin{array}{l}0.007 \\
(2.25)\end{array}$ & -0.003 \\
\hline No A-level & $\begin{array}{l}0.035 \\
(0.90)\end{array}$ & $\begin{array}{l}0.065 \\
(1.23)\end{array}$ & $\begin{array}{l}0.046 \\
(1.25)\end{array}$ & 0.002 \\
\hline 60's university & $\begin{array}{l}-0.028 \\
(1.27)\end{array}$ & $\begin{array}{l}-0.043 \\
(2.34)\end{array}$ & $\begin{array}{c}-0.034 \\
(2.16)\end{array}$ & 0.000 \\
\hline 90's university & $\begin{array}{l}-0.066 \\
(3.62)\end{array}$ & $\begin{array}{l}-0.073 \\
(2.69)\end{array}$ & $\begin{array}{l}-0.073 \\
(4.05)\end{array}$ & 0.000 \\
\hline college of $\mathrm{HE}$ & $\begin{array}{l}-0.088 \\
(4.78)\end{array}$ & $\begin{array}{l}-0.095 \\
(2.59)\end{array}$ & $\begin{array}{l}-0.095 \\
(6.21)\end{array}$ & 0.001 \\
\hline Degree class $2 / 1$ & $\begin{array}{l}-0.082 \\
(4.02)\end{array}$ & $\begin{array}{l}-0.052 \\
(2.77)\end{array}$ & $\begin{array}{l}-0.067 \\
(5.14)\end{array}$ & -0.003 \\
\hline Degree class $2 / 2$ & $\begin{array}{r}-0.120 \\
(6.24)\end{array}$ & $\begin{array}{l}-0.121 \\
(5.04)\end{array}$ & $\begin{array}{r}-0.117 \\
(8.71)\end{array}$ & 0.000 \\
\hline Degree class 3 & $\begin{array}{l}-0.095 \\
(2.71)\end{array}$ & $\begin{array}{l}-0.108 \\
(4.25)\end{array}$ & $\begin{array}{l}-0.097 \\
(4.14)\end{array}$ & 0.000 \\
\hline Diploma & $\begin{array}{l}-0.024 \\
(1.63)\end{array}$ & $\begin{array}{l}-0.039 \\
(1.87)\end{array}$ & $\begin{array}{l}-0.027 \\
(2.67)\end{array}$ & 0.001 \\
\hline Professional qual & $\begin{array}{l}0.027 \\
(1.51)\end{array}$ & $\begin{array}{l}-0.024 \\
(1.37)\end{array}$ & $\begin{array}{l}0.001 \\
(0.06)\end{array}$ & 0.000 \\
\hline Masters & $\begin{array}{l}-0.062 \\
(3.58)\end{array}$ & $\begin{array}{l}-0.035 \\
(1.71)\end{array}$ & $\begin{array}{l}-0.050 \\
(3.63)\end{array}$ & 0.000 \\
\hline Ph.D & $\begin{array}{l}-0.039 \\
(1.01)\end{array}$ & $\begin{array}{l}-0.052 \\
(1.80)\end{array}$ & $\begin{array}{l}-0.049 \\
(2.25)\end{array}$ & 0.000 \\
\hline Humanities & $\begin{array}{l}0.009 \\
(0.59)\end{array}$ & $\begin{array}{l}0.069 \\
(1.90)\end{array}$ & $\begin{array}{l}0.024 \\
(1.67)\end{array}$ & -0.002 \\
\hline Languages & $\begin{array}{l}0.084 \\
(4.01)\end{array}$ & $\begin{array}{l}0.006 \\
(0.13)\end{array}$ & $\begin{array}{l}0.073 \\
(5.19)\end{array}$ & 0.004 \\
\hline Law & $\begin{array}{l}0.061 \\
(1.93)\end{array}$ & $\begin{array}{l}0.140 \\
(4.80)\end{array}$ & $\begin{array}{l}0.098 \\
(3.83)\end{array}$ & 0.000 \\
\hline Social sciences & $\begin{array}{l}0.047 \\
(3.45)\end{array}$ & $\begin{array}{l}0.105 \\
(3.43)\end{array}$ & $\begin{array}{l}0.064 \\
(4.34)\end{array}$ & -0.001 \\
\hline Maths \& computing & $\begin{array}{l}0.180 \\
(7.84)\end{array}$ & $\begin{array}{l}0.273 \\
(7.20)\end{array}$ & $\begin{array}{l}0.232 \\
(8.90)\end{array}$ & 0.005 \\
\hline Natural science & $\begin{array}{l}0.020 \\
(1.10)\end{array}$ & $\begin{array}{l}0.067 \\
(2.49)\end{array}$ & $\begin{array}{l}0.040 \\
(2.63)\end{array}$ & 0.001 \\
\hline Medicine \& related & $\begin{array}{l}0.196 \\
(6.52)\end{array}$ & $\begin{array}{l}0.342 \\
(5.02)\end{array}$ & $\begin{array}{l}0.232 \\
(7.16)\end{array}$ & -0.006 \\
\hline Engineering & $\begin{array}{l}0.139 \\
(4.23)\end{array}$ & $\begin{array}{l}0.168 \\
(5.95)\end{array}$ & $\begin{array}{c}0.148 \\
(7.91)\end{array}$ & 0.006 \\
\hline Business studies & $\begin{array}{l}0.133 \\
(7.99)\end{array}$ & $\begin{array}{l}0.163 \\
(5.19)\end{array}$ & $\begin{array}{l}0.145 \\
(8.74)\end{array}$ & 0.001 \\
\hline Education & $\begin{array}{l}0.059 \\
(2.81)\end{array}$ & $\begin{array}{l}0.051 \\
(0.76)\end{array}$ & $\begin{array}{l}0.068 \\
(3.29)\end{array}$ & 0.000 \\
\hline Other vocational & $\begin{array}{l}0.072 \\
(2.40)\end{array}$ & $\begin{array}{l}0.094 \\
(2.82)\end{array}$ & $\begin{array}{l}0.072 \\
(3.36)\end{array}$ & 0.000 \\
\hline Interdisciplinary & $\begin{array}{l}0.098 \\
(2.96)\end{array}$ & $\begin{array}{l}0.082 \\
(1.67)\end{array}$ & $\begin{array}{l}0.087 \\
(3.03)\end{array}$ & 0.000 \\
\hline Firm size $10-24$ & $\begin{array}{l}0.053 \\
(1.97)\end{array}$ & $\begin{array}{l}0.063 \\
(1.31)\end{array}$ & $\begin{array}{l}0.056 \\
(2.24)\end{array}$ & -0.001 \\
\hline
\end{tabular}




\begin{tabular}{|c|c|c|c|c|}
\hline Firm size $25-49$ & $\begin{array}{l}0.063 \\
(2.57)\end{array}$ & $\begin{array}{l}0.020 \\
(0.41)\end{array}$ & $\begin{array}{l}0.046 \\
(2.02)\end{array}$ & 0.002 \\
\hline \multirow[t]{2}{*}{ Firm size 50 - 249} & 0.063 & 0.075 & 0.060 & 0.000 \\
\hline & $(2.63)$ & $(1.84)$ & $(2.42)$ & \\
\hline \multirow[t]{2}{*}{ Firm size 250 - 499} & 0.067 & 0.123 & 0.091 & 0.001 \\
\hline & $(2.20)$ & $(3.24)$ & $(3.52)$ & \\
\hline \multirow[t]{2}{*}{ Firm size 500 or more } & 0.129 & 0.173 & 0.147 & 0.004 \\
\hline & $(5.39)$ & $(4.44)$ & (5.99) & \\
\hline \multirow[t]{2}{*}{$\%$ Female } & -0.002 & -0.001 & -0.002 & -0.013 \\
\hline & $(5.71)$ & $(2.90)$ & $(7.05)$ & \\
\hline \multirow[t]{2}{*}{ Permanent job } & 0.091 & 0.158 & 0.114 & 0.002 \\
\hline & $(5.31)$ & (7.19) & $(7.64)$ & \\
\hline \multirow[t]{2}{*}{ Public sector } & 0.078 & 0.100 & 0.090 & 0.001 \\
\hline & $(3.27)$ & $(3.34)$ & $(4.86)$ & \\
\hline \multirow[t]{2}{*}{ Professional } & 0.024 & -0.024 & -0.000 & 0.001 \\
\hline & $(1.01)$ & $(1.21)$ & $(0.01)$ & \\
\hline \multirow[t]{2}{*}{ Associate } & -0.017 & -0.042 & -0.033 & -0.001 \\
\hline & $(0.74)$ & $(2.51)$ & $(2.29)$ & \\
\hline \multirow[t]{2}{*}{ Clerical } & -0.066 & -0.145 & -0.095 & 0.004 \\
\hline & $(2.09)$ & $(3.91)$ & $(4.33)$ & \\
\hline \multirow[t]{2}{*}{ other } & -0.089 & -0.142 & -0.117 & -0.002 \\
\hline & $(3.00)$ & $(6.57)$ & $(6.38)$ & \\
\hline \multirow[t]{2}{*}{ Career development } & -0.028 & 0.002 & -0.017 & 0.004 \\
\hline & $(3.00)$ & $(0.13)$ & $(1.90)$ & \\
\hline \multirow[t]{2}{*}{ Personal development } & 0.008 & 0.012 & 0.008 & 0.000 \\
\hline & $(0.68)$ & $(0.80)$ & $(0.75)$ & \\
\hline \multirow[t]{2}{*}{ Job satisfaction } & 0.002 & -0.004 & -0.002 & 0.001 \\
\hline & $(0.13)$ & $(0.31)$ & $(0.20)$ & \\
\hline \multirow[t]{2}{*}{ Financial reward } & 0.041 & 0.056 & 0.048 & 0.003 \\
\hline & $(6.87)$ & $(6.12)$ & $(8.66)$ & \\
\hline \multirow[t]{2}{*}{ Status and respect } & 0.018 & 0.002 & 0.012 & 0.001 \\
\hline & $(2.97)$ & $(0.38)$ & $(2.85)$ & \\
\hline \multirow[t]{2}{*}{ Valued by employer } & 0.000 & -0.002 & 0.001 & 0.000 \\
\hline & $(0.00)$ & $(0.10)$ & $(0.07)$ & \\
\hline \multirow[t]{2}{*}{ Socially useful job } & -0.010 & -0.021 & -0.017 & 0.006 \\
\hline & $(1.55)$ & $(2.50)$ & $(3.40)$ & \\
\hline International & 0.010 & 0.018 & 0.014 & 0.002 \\
\hline experience & $(1.96)$ & $(2.43)$ & $(4.07)$ & \\
\hline Rewarding leisure & 0.004 & 0.012 & 0.006 & 0.000 \\
\hline & $(0.87)$ & $(1.70)$ & $(1.63)$ & \\
\hline Concern: local issues & -0.010 & -0.007 & -0.010 & 0.000 \\
\hline & $(1.49)$ & $(0.69)$ & $(2.02)$ & \\
\hline Concern: ecology & -0.008 & -0.023 & -0.017 & 0.003 \\
\hline & $(1.72)$ & $(2.65)$ & $(3.53)$ & \\
\hline Concern: c. affairs & 0.004 & 0.009 & 0.009 & 0.000 \\
\hline & $(0.75)$ & $(1.30)$ & $(2.45)$ & \\
\hline Ambitious & 0.036 & 0.041 & 0.037 & 0.001 \\
\hline & $(5.20)$ & $(3.92)$ & $(6.33)$ & \\
\hline Fulfilment from work & 0.005 & -0.009 & -0.001 & -0.001 \\
\hline & $(1.12)$ & $(1.69)$ & $(0.34)$ & \\
\hline I live to work & 0.000 & 0.007 & 0.004 & 0.001 \\
\hline & $(0.03)$ & $(0.72)$ & $(0.78)$ & \\
\hline I work to live & 0.002 & -0.001 & 0.002 & 0.000 \\
\hline & $(0.30)$ & $(0.12)$ & $(0.55)$ & \\
\hline Work til retirement & -0.027 & -0.026 & -0.028 & 0.001 \\
\hline & $(4.83)$ & $(4.62)$ & $(7.45)$ & \\
\hline Career breaks & -0.003 & -0.009 & -0.013 & 0.008 \\
\hline & $(0.58)$ & $(1.05)$ & $(2.97)$ & \\
\hline Partner take breaks & -0.006 & 0.030 & 0.016 & 0.019 \\
\hline
\end{tabular}




\begin{tabular}{lcccc} 
& $(1.64)$ & $(3.79)$ & $(4.71)$ & \\
Career change & 0.000 & -0.008 & -0.004 & -0.001 \\
& $(0.10)$ & $(1.49)$ & $(0.99)$ & \\
Constant & 9.686 & 9.703 & 9.701 & \\
& $(130.16)$ & $(87.15)$ & $(140.69)$ & \\
Observations & 2967 & 2220 & 5187 & \\
R-squared & 0.37 & 0.41 & 0.39 & \\
\hline
\end{tabular}

Note: Also include dummies for region of residence.

Standard error are corrected for clustering at the institution level 


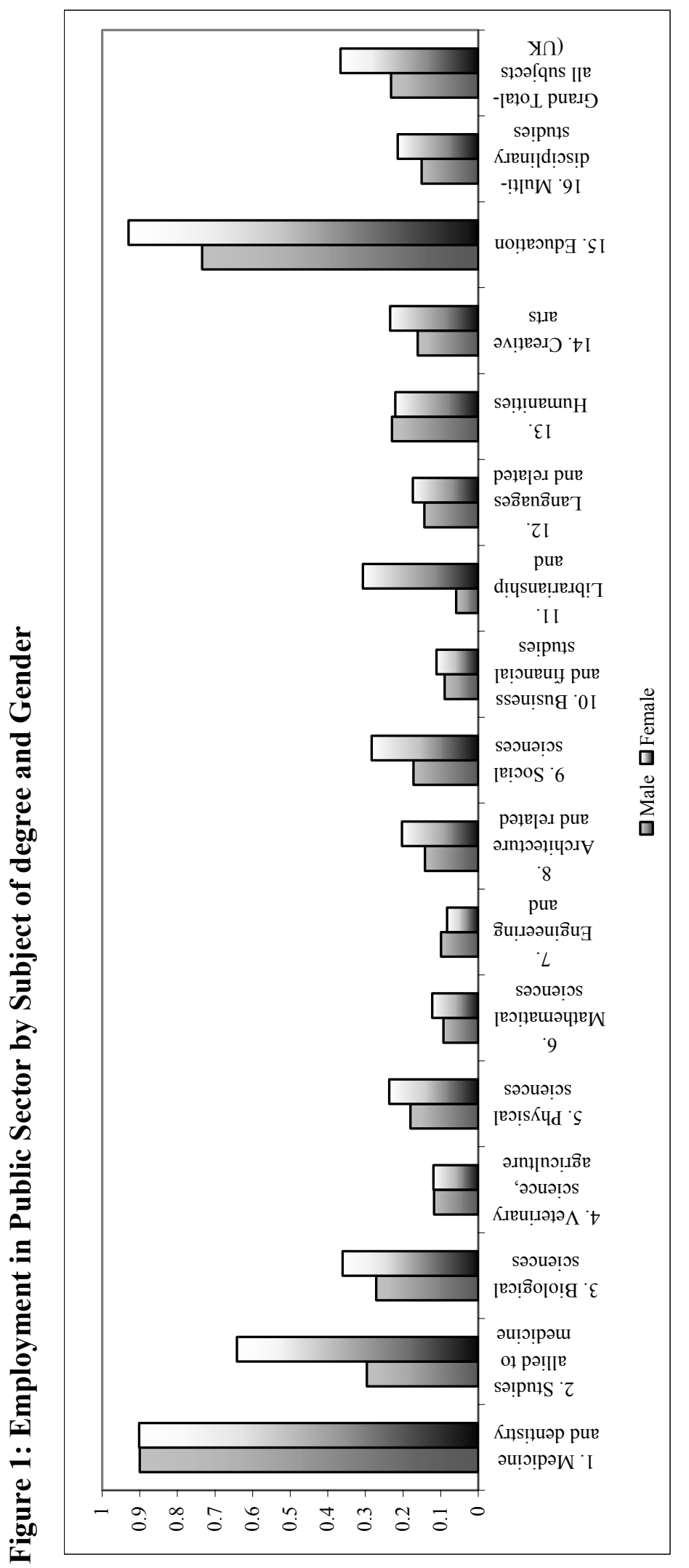

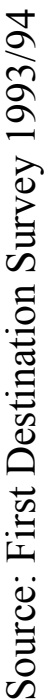


Figure 2: Yearly wage distribution by gender- Cohort 1995

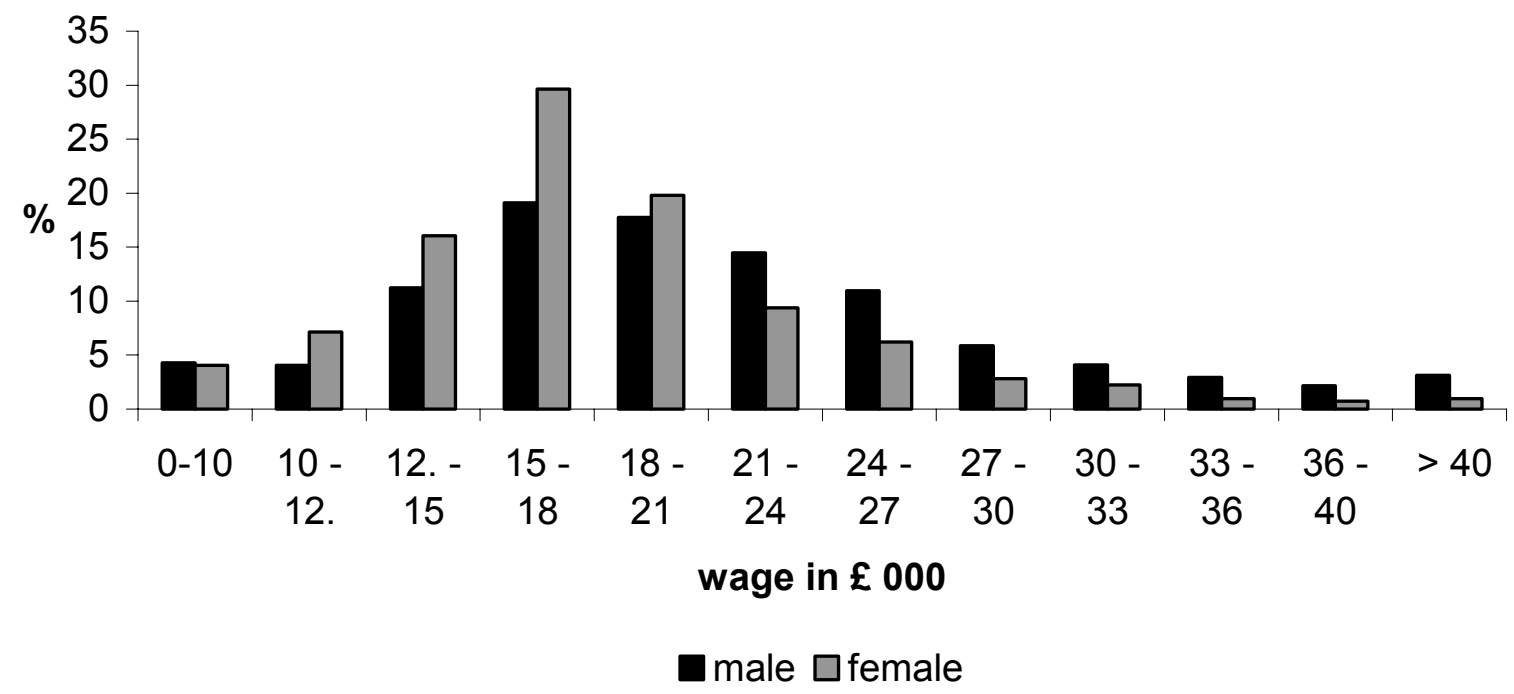

